\title{
The Metabolism of the Amino Acids of Escherichia coli and Other Bacteria by the Rumen Ciliate Entodinium caudatum
}

\author{
By G. S. COLEMAN \\ Biochemistry Department, Agricultural Research Council, Institute \\ of Animal Physiology, Babraham, Cambridge
}

(Accepted for publication 30 January 1967)

\begin{abstract}
SUMMARY
Non-multiplying and growing cultures of Entodinium caudatum incubated anaerobically engulfed Escherichia coli bacteria specifically labelled with individual ${ }^{14} \mathrm{C}$-amino acids and incorporated the amino acids into protozoal protein without conversion to any other amino acid. The protozoal cisternae 'pool' and the medium contained the free amino acid and with some amino acids the $N$-acetyl or $N$-formyl derivative in addition. The constituents of the pool were probably by-products of the metabolism of the bacteria and not intermediates between bacterial and protozoal proteins. There was no extensive catabolism of the bacterial amino acids by the protozoa, although some of the bacterial leucine, isoleucine and valine was broken down to isovaleric acid, $\alpha$-methylbutyric acid and isobutyric acid, respectively. The addition to the medium of the ${ }^{12} \mathrm{C}$-form of the ${ }^{14} \mathrm{C}$-amino acid present in the $E$. coli decreased the incorporation of ${ }^{14} \mathrm{C}$ into the protozoa with half of the amino acids tested. The rate of loss of viability of various other bacterial species after engulfment by the protozoa was found to be independent of Gram-reaction, size or natural habitat.
\end{abstract}

\section{INTRODUCTION}

It was shown by Coleman (1964) that washed suspensions of Entodinium caudatum grown in vitro engulfed bacteria from the medium and that when the bacterium studied was Escherichia coli this was rapidly killed and digested. The digestion products were then liberated into the medium or incorporated into protozoal protoplasm. It was also shown that when the protozoa were offered two different species of bacteria, these were engulfed in the proportion in which they were present in the medium. The purpose of the present paper is to extend these studies by investigating the fate of these bacteria inside the protozoa and by the use of bacteria specifically labelled with ${ }^{14} \mathrm{C}$-amino acids to elucidate the metabolism of these amino acids by the protozoa.

\section{METHODS}

Source of protozoa. Entodinium caudatum was grown and inoculum cultures prepared and treated as described by Coleman (1962) except that inoculum cultures were treated each day with $15 \mathrm{mg}$. rice starch and about $10 \mathrm{mg}$. dried grass.

Preparation of protozoa for inoculation. The protozoa were taken from the inoculum cultures in which they were present as a loose pellet at the bottom of the tube, after removal of the surface scum and most of the medium, and allowed to stand in $8 \times 1 \mathrm{in}$. 
tubes until any grass present had sunk to the bottom, leaving the protozoa in the supernatant fluid. This supernatant fluid was transferred to centrifuge tubes, the residual grass washed with salt solution B (Coleman, 1960) and the washings added to the supernatant fluid. The protozoa were spun down and washed three times in salt solution B which contained $0.03 \%$ cysteine, on a bucket-head centrifuge for $20 \mathrm{sec}$. from starting; the maximum speed was equivalent to $200 \mathrm{~g}$. For experiments with nonmultiplying protozoa the organisms were finally used as inoculum to give a population density of $3-7 \times 10^{4}$ protozoa $/ \mathrm{ml}$. except in experiments on the constituents of the pool where concentrations up to $50 \times 10^{4}$ protozoa $/ \mathrm{ml}$. were used. For growth experiments $1-2 \times 10^{4}$ protozoa $/ \mathrm{ml}$. incubation medium were used.

Incubation conditions for engulfment of bacteria by non-multiplying protozoa. The medium consisted of $1.8-8.2 \mathrm{ml}$. (chosen so that the final volume was $10 \mathrm{ml}$.) salt solution B (Coleman, 1960), 0-6.0 ml. water, 0-6.0 ml. double-strength salt solution B and amino acids (if any) autoclaved ( $115^{\circ}$ for $20 \mathrm{~min}$.) in a $15 \mathrm{ml}$. centrifuge tube. Standard salt solution contained $7.4 \mathrm{ml}$. salt solution $\mathrm{B}, 2.2 \mathrm{ml}$. water, and cysteine and $\mathrm{NaHCO}_{3}$ as described below. The concentration was altered by replacing the salt solution by water or the water and salt solution by salt solution of double the normal concentration. Immediately after removal from the autoclave the following additions were made aseptically: $0.2 \mathrm{ml} .1 \%$ L-cysteine hydrochloride (neutralized and Seitz filtered), $0.2 \mathrm{ml} .5 \%(\mathrm{w} / \mathrm{v}) \mathrm{NaHCO}_{3}$ (Seitz filtered), $0 \cdot 1-2.0 \mathrm{ml}$. suspension of ${ }^{14} \mathrm{C}-$ bacteria in salt solution $B$ (washed once and suspended at a concentration of $10^{8}-10^{10}$ bacteria/ml.) and any other additions. After inoculation the tubes were gassed for 10 sec. with $95 \%(\mathrm{v} / \mathrm{v}) \mathrm{N}_{2}+5 \%(\mathrm{v} / \mathrm{v}) \mathrm{CO}_{2}$, sealed with a rubber bung and incubated at $39^{\circ}$ except where otherwise stated.

Incubation conditions for metabolism of bacteria by growing protozoa. The medium and conditions used were those of Coleman (1964). At the end of experiments in which the uptake of ${ }^{14} \mathrm{C}$-bacteria was being investigated the protozoa were centrifuged down and washed twice in salt solution $B$ on a bucket-head centrifuge for $30 \mathrm{sec}$. from starting (maximum speed was equivalent to $300 \mathrm{~g}$ ). Under these conditions less than $1 \%$ of the free bacteria were sedimented with the protozoa. The washed protozoa were then plated out to determine radioactivity or, in experiments to measure the viability of intracellular bacteria, broken in a Potter homogenizer (Potter \& Elvehjem, 1936) at room temperature until $98-100 \%$ of the protozoa were broken (usually about $90 \mathrm{sec}$.). The residual bacteria were spun down from the first supernatant fluid obtained after removal of the protozoa and washed once at $2000 \mathrm{~g}$ for $10 \mathrm{~min}$. on an angle-head centrifuge. Samples from the supernatant fluid after removal of the bacteria were placed on planchets with $0 \cdot 1 \mathrm{ml}$. N-HCl or $0.1 \mathrm{ml} .0 \cdot 1 \mathrm{~N}-\mathrm{NaOH}$ for the estimation of the ${ }^{14} \mathrm{C}$ which was free in the medium. The radioactivity determined in the presence of $\mathrm{HCl}$ measured the non-volatile ${ }^{14} \mathrm{C}$ and the difference between the determinations in the presence of $\mathrm{HCl}$ and $\mathrm{NaOH}$ the volatile ${ }^{14} \mathrm{C}$.

Sources of bacteria. See Coleman (1964). Bacteria 7G2, 21 G13/1, 23G3/2 were isolated from inside washed protozoa (White, 1966).

Bacterial growth media. Escherichia coli was grown and maintained at $39^{\circ}$ in $\mathrm{C}$ medium (Roberts et al. 1955) containing $0.2 \%$ (w/v) glucose and aerated during incubation by passing sterile air into the medium through a cottonwool-plugged Pasteur pipette. To obtain bacteria uniformly labelled with ${ }^{14} \mathrm{C}, 0.05 \mu \mathrm{C}$ [U-14 C]glucose/ml. was added to the growth medium. To obtain $E$. coli specifically labelled 
with one ${ }^{14} \mathrm{C}$-amino acid the bacteria were grown in $\mathrm{C}$ medium $+0.2 \%$ glucose +0.02 $\mu \mathrm{C}{ }^{14} \mathrm{C}$-amino acid $/ \mathrm{ml}$. + those ${ }^{12} \mathrm{C}$-amino acids (each at $0.015 \mathrm{M}$ ) required to prevent the passage of ${ }^{14} \mathrm{C}$ into other amino acids of the bacteria. The amino acids and other compounds added with ${ }^{14} \mathrm{C}$-alanine were ${ }^{12} \mathrm{C}$-aspartic acid, glutamic acid, leucine, serine, valine; with ${ }^{14} \mathrm{C}$-glutamic acid were ${ }^{12} \mathrm{C}$-arginine, aspartic acid, proline; with ${ }^{14} \mathrm{C}$-glycine were ${ }^{12} \mathrm{C}$-adenine, alanine, aspartic acid, glutamic acid, pyruvic acid, serine; with ${ }^{14} \mathrm{C}$-lysine were ${ }^{12} \mathrm{C}$-arginine, glutamic acid, isoleucine, proline, threonine; with ${ }^{14} \mathrm{C}$-phenylalanine were ${ }^{12} \mathrm{C}$-aspartic acid, glutamic acid, tyrosine; with ${ }^{14} \mathrm{C}$ proline were ${ }^{12} \mathrm{C}$-arginine, glutamic acid; with ${ }^{14} \mathrm{C}$-serine were ${ }^{12} \mathrm{C}$-adenine, alanine, aspartic acid, cysteine, glycine, glutamic acid, pyruvic acid; with ${ }^{14} \mathrm{C}$-valine was ${ }^{12} \mathrm{C}$-leucine; with ${ }^{14} \mathrm{C}$-leucine and ${ }^{14} \mathrm{C}$-isoleucine, no additions.

Other bacteria were grown at $37^{\circ}$ for $16 \mathrm{hr}$ in a medium that contained (per litre): salt solution (Coleman, 1958), $250 \mathrm{ml}$.; Difco yeast extract, 2 g.; Difco tryptose, 2 g.; glucose, 2 g.; [8-14 C]guanine, $14 \mu \mathrm{C}$ (if any). Serratia marcescens and Bacterium 31 were able to grow on $\mathrm{C}$ medium (Roberts et al. 1955) containing $0.2 \%$ glucose, and where it was required to label the bacteria with a ${ }^{14} \mathrm{C}$-amino acid this medium was used. All the bacteria were grown aerobically in static culture in cottonwool-plugged flasks except for Clostridium welchii which was grown under $\mathrm{CO}_{2}$ and Escherichia coli which was grown with forced aeration.

Nadsonia elongata was grown at $30^{\circ}$ in cottonwool-plugged flasks for $16 \mathrm{hr}$ in a medium that contained (per litre): $\left(\mathrm{NH}_{4}\right)_{2} \mathrm{SO}_{4}, 2 \mathrm{~g}$.; $\mathrm{KH}_{2} \mathrm{PO}_{4}, 2 \mathrm{~g}$.; Difco yeast extract, 5 g.; glucose 2 g.

Bacterial viable counts. Colony counts of Escherichia coli were made by serial 10-fold dilutions in $\mathrm{C}$ medium $+0.2 \%(\mathrm{w} / \mathrm{v})$ glucose (Roberts et al. 1955) followed by plating on $\mathrm{C}$ medium containing $0.2 \%(\mathrm{w} / \mathrm{v})$ glucose and $1 \%(\mathrm{w} / \mathrm{v})$ agar and incubation at $39^{\circ}$. Colony counts of other bacteria were made by serial 10 -fold dilutions in medium which contained (per litre): salt solution (Coleman, 1958), $250 \mathrm{ml}$.; Difco yeast extract, 2 g.; Difco tryptose, $2 \mathrm{~g}$.; glucose $2 \mathrm{~g}$.; followed by plating on the same medium plus $1 \%$ agar and incubation aerobically, except for Clostridium welchii which was incubated anaerobically at $39^{\circ}$.

Colony counts of Nadsonia elongata were made by serial 10 -fold dilutions in its growth medium, followed by plating on this medium solidified with $1 \%$ agar and incubation at $30^{\circ}$.

Total bacterial counts. The total number of bacteria in a washed bacterial suspension was estimated by counting an appropriate dilution in a Helber counting chamber of depth $0.02 \mathrm{~mm}$. and square size $0.0025 \mathrm{~mm}^{2}$.

Protozoal counts. The numbers of protozoa were estimated by the method of Coleman (1958). Only those protozoa which showed no sign of disintegration were counted.

Estimation of ${ }^{14} C .{ }^{14} \mathrm{C}$ in whole protozoa was estimated by washing the organisms with water on to an aluminium disc (planchet) of area $4.7 \mathrm{~cm} .{ }^{2}$ and carrying a disc of lens tissue. The sample was spread by one drop of cetyltrimethylammonium bromide solution $(5 \mathrm{mg} . / \mathrm{ml}$.) and fixed with one drop of polyvinyl alcohol $(2 \mathrm{mg} . / \mathrm{ml}$.), the disc was dried at $40^{\circ}$, and the ${ }^{14} \mathrm{C}$ estimated by using an automatic flow-counter (NuclearChicago Corp.) with an efficiency of about $20 \%$. Over 1000 counts at a rate greater than five times background were recorded for all fractions. Determinations were made with less than $0.5 \mathrm{mg}$. of material $/ \mathrm{cm}^{2}$ of disc. To determine the relative ${ }^{14} \mathrm{C}$ contents of spots on chromatograms a thin mica end-window GM tube was placed directly 
on a spot, the position of which had been determined by radio-autography. ${ }^{14} \mathrm{CO}_{2}$ was determined by the method of Coleman (1956).

Fractionation of organisms, paper chromatography, identification of ${ }^{14} \mathrm{C}$-labelled compounds in the medium and the protozoal 'pool', chemicals. See Coleman (1967).

\section{RESULTS}

\section{Loss of viability of engulfed bacteria}

Although it had been shown previously (Coleman, 1964) that many species of bacteria were engulfed by Entodinium caudatum and that Escherichia coli was rapidly killed after uptake, no studies were reported on the killing of other bacterial species. In an attempt to measure this loss of viability, the bacteria were first labelled by growth on a suitable medium in the presence of a ${ }^{14} \mathrm{C}$-labelled compound which was usually $\left[8-{ }^{14} \mathrm{C}\right]$ guanine where a complex growth medium was used. This tracer was used in preference to ${ }^{14} \mathrm{C}$-glucose or a ${ }^{14} \mathrm{C}$-amino acid under these conditions because these latter compounds gave poor labelling of the bacteria. The use of guanine-labelled bacteria had the disadvantage that more ${ }^{14} \mathrm{C}$ was liberated into the medium after prolonged incubation in the absence of protozoa, but provided that incubations of less than $3 \mathrm{hr}$ were used, the amount released was small.

The number of bacteria engulfed was determined after incubation of the protozoa with bacteria of known specific activity by measuring the ${ }^{14} \mathrm{C}$ in the protozoa. The number of viable bacteria in the medium in the absence of protozoa was measured initially and at the end of the experiment to obtain an estimate of the loss of viability of the bacterium in the protozoal incubation medium. The number of viable bacteria present in the washed protozoa was measured before and after breakage of the protozoa in a Potter homogenizer (Potter \& Elvehjem, 1936) initially, and after incubation in the presence or absence of bacteria. In all experiments corrections were applied for initial values and the bacteria present with unbroken protozoa, but these were usually less than $10 \%$ of the count in protozoa broken after incubation with bacteria.

The results obtained for average bacterial survival after incubation for $2.5 \mathrm{hr}$ of protozoa with various species of bacteria are shown in Table 1 . There was considerable variation between experiments with different batches of protozoa in the percentage survival of the same bacterial species, e.g. Escherichia coli survival varied from 0.7 to $13 \%$ and Serratia marcescens survival from 36 to $84 \%$. It was apparent that the resistance of any bacterial species is not related to Gram reaction, bacterial shape or size or to the source from which the bacterium was originally isolated. The three members of the Enterobacteriacae-E. coli, Proteus vulgaris, and S. marcescens-had widely different survivals inside the protozoa. The bacteria isolated from suspensions of Entodinium caudatum immediately after separation from the growth medium, namely Bacterium 31, Bacterium D, 7G2, 21 G13/1 and 23G3/2 (White, 1966) had survival percentages of 7-82\% and were therefore not particularly resistant to killing. It is possible, especially with Bacterium 31 which was found in larger numbers than the other bacteria inside the protozoa and which produced slime when grown in the presence of glucose, that bacteria which are found inside the protozoa may produce some kind of protective envelope in that environment.

Studies on the effect of the salt concentration in the medium on bacterial survival 
showed in one experiment that when the salt concentration was altered from 100 to $50 \%$, the number of surviving Escherichia coli decreased from 3.0 to $1.7 \%$ and that at $200 \%$ of standard salt concentration it increased to $7.5 \%$. For Serratia marcescens the corresponding survivals were $30 \%, 68 \%, 69 \%$ at $50 \%, 100 \%$ and $200 \%$ of standard salt concentration. Variation in the population density of $E$. coli from $1 \cdot 2 \times 10^{9}$ to $19 \times 10^{9} / \mathrm{ml}$. did not affect the survival of bacteria inside the protozoa. All the results quoted above probably give a high estimate of the number of bacterial survivors after $2.5 \mathrm{hr}$ because the protozoa engulf bacteria throughout the incubation period and those which have just been engulfed obviously have more chance of survival than those engulfed at the beginning of the experiment.

\section{Table 1. The viability of bacteria engulfed by Entodinium caudatum}

Entodinium caudatum (approximately $5 \times 10^{4}$ protozoa $/ \mathrm{ml}$.) was incubated anaerobically in the presence of approximately $10^{9} / \mathrm{ml} .{ }^{14} \mathrm{C}$-labelled bacteria of known specific activity for $2.5 \mathrm{hr}$. The number of bacteria taken up was calculated from the ${ }^{14} \mathrm{C}$ in the protozoa at the end of the experiment and the number of viable bacteria inside the protozoa from the difference in colony count before and after breakage of the protozoa in a Potter homogenizer. The viability of the bacteria in the absence of protozoa was also measured.

\section{Micro-organism}

Clostridium welchii

Escherichia coli

Lactobacillus casei

Proteus vulgaris

Serratia marcescens

Staphylococcus aureus

Streptococcus bovis

Bacterium D

Bacterium 31

$7 \mathrm{G} 2$

$21 \mathrm{G} 13 / 1$

$23 \mathrm{G} 3 / 2$

Nadsonia elongata

\section{Description}

Gram + ve rod

Gram - ve rod

Gram + ve rod

Gram-ve rod

Gram-ve rod

Gram + ve coccus

Gram + ve coccus (from rumen)

Gram + ve coccus (from protozoa)

Gram - ve rod (from protozoa)

Gram - ve rod (from protozoa)

Gram + ve coccus (from protozoa)

Gram + ve rod (from protozoa)

A yeast

$\begin{array}{cc}\begin{array}{c}\text { Proportion } \\ \text { of engulfed } \\ \text { micro- } \\ \text { organism } \\ \text { still } \\ \text { viable } \\ \text { after } 2 \cdot 5 \text { hr } \\ (\%)\end{array} & \begin{array}{c}\text { Micro- } \\ \text { organism } \\ \text { survival } \\ \text { in } \\ \text { absence of } \\ \text { protozoa }\end{array} \\ (\% \cdot 5 & (\%) \\ 0 \cdot 7-12 \cdot 5 & 55 \\ 1 \cdot 7 & 100 \\ 23 & 100 \\ 60 & 90 \\ 2 & 70 \\ 1-7 & 15 \\ 42 & 70 \\ 35 & 100 \\ 82 & 90 \\ 7 & 100 \\ 8-70 & 27 \\ 1 & 95 \\ & 20\end{array}$

The metabolism of Serratia marcescens by Entodinium caudatum

Although Serratia marcescens and Escherichia coli are both short Gram-negative rods the former was far more resistant to killing by the protozoa than was the latter. Since $S$. marcescens tended to grow in small clumps it was possible that where each clump would give rise to one colony in the viable count assay, it would be necessary for only one bacterium in each clump to remain viable for the count to be unchanged. To investigate this further, the digestion of suspensions of $S$. marcescens or $E$. coli containing equal numbers of bacteria and labelled with ${ }^{14} \mathrm{C}$-leucine was compared. Table 2 shows that when $S$. marcescens was engulfed: $(a)$ less ${ }^{14} \mathrm{C}$ appeared in the supernatant fluid; (b) a smaller proportion of the total protozoal ${ }^{14} \mathrm{C}$ was present in the broken protozoal supernatant fluid (i.e. more ${ }^{14} \mathrm{C}$ was in the broken protozoal pellet which contained any intact bacteria); $(c){ }^{12} \mathrm{C}$-leucine free in the medium had 
much less effect on the total ${ }^{14} \mathrm{C}$ found in the protozoa. These results are consistent with the hypothesis that $S$. marcescens was digested much more slowly than was E. coli.

\section{Table 2. The metabolism of Escherichia coli and Serratia marcescens labelled with ${ }^{14} \mathrm{C}$-leucine}

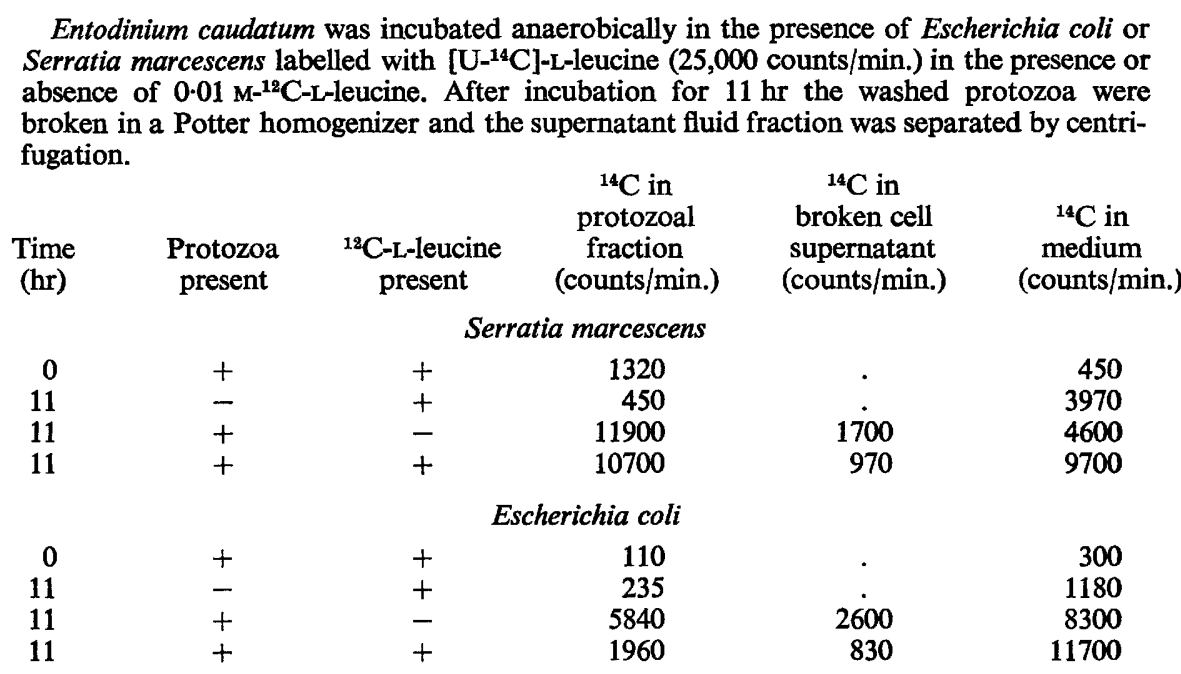

Effect of amino acids on the engulfment of Escherichia coli by Entodinium caudatum

In many of the experiments to be reported below the specific action of a free ${ }^{12} \mathrm{C}$ amino acid on the incorporation of ${ }^{14} \mathrm{C}$ from Escherichia coli labelled with the ${ }^{14} \mathrm{C}$ form of that amino acid was investigated, and it was therefore first necessary to study the action of amino acids on the engulfment of uniformly ${ }^{14} \mathrm{C}$-labelled $E$. coli. When incubations were continued for $5 \mathrm{hr}$ or longer the ${ }^{14} \mathrm{C}$ incorporated into protozoa under these conditions was altered by less than $10 \%$ when the following amino acids were added at a concentration of $0.01 \mathrm{M}$ : L-alanine, L-aspartic acid, L-arginine, L-asparagine, L-cysteine, L-glutamic acid, L-histidine, L-isoleucine, L-leucine, L-lysine, L-phenylalanine, L-serine, DL-threonine, L-valine. In contrast, $0.01 \mathrm{M}$-L-proline or glycine decreased the incorporation by $40 \%$ after $30 \mathrm{~min}$. or $5 \mathrm{hr}$ of incubation. However, over the first $30 \mathrm{~min}$. incubation $0.01 \mathrm{M}$-L-lysine or L-arginine stimulated the incorporation of ${ }^{14} \mathrm{C}$ by $50 \%$ and $0.01 \mathrm{M}-\mathrm{L}$-cysteine, additional to that in the basal medium, by $70 \%$. An increase in the concentration of L-arginine to $0.02 \mathrm{M}$ and $\mathrm{L}$ cysteine to $0.04 \mathrm{~m}$ increased this stimulation by a further $15 \%$ and $20-150 \%$, respectively. Figure 1 shows the time-course for incubation under these conditions and shows that after the first hour the rate of ${ }^{14} \mathrm{C}$ incorporation was approximately the same whether in the presence or in the absence of arginine and cysteine. The proportion of the engulfed bacteria that had been rendered non-viable after $1 \mathrm{hr}$ was the same under all conditions. The stimulation by L-cysteine was not due solely to its action as a reducing agent because $0.01 \mathrm{M}$-sodium thioglycollate (mercaptoacetate), which has the same $E_{0}^{\prime}$ as cysteine, produced only $60 \%$ of the stimulation caused by the presence of $0.01 \mathrm{M}$-L-cysteine; $0.01 \mathrm{M}$-2-mercaptoethanol killed the protozoa. 


\section{Metabolism of ${ }^{14} \mathrm{C}$-amino acid labelled Escherichia coli by non-multiplying Entodinium caudatum}

Escherichia coli were prepared labelled with one ${ }^{14} \mathrm{C}$-amino acid by growth on a glucose + ammonia + salts medium (C medium of Roberts et al. 1955) and tracer quantities of the relevant ${ }^{14} \mathrm{C}$-amino acid + those ${ }^{12} \mathrm{C}$-amino acids found by Roberts et al. (1955) or the present author's own experience to prevent the incorporation of ${ }^{14} \mathrm{C}$ into other amino acids.

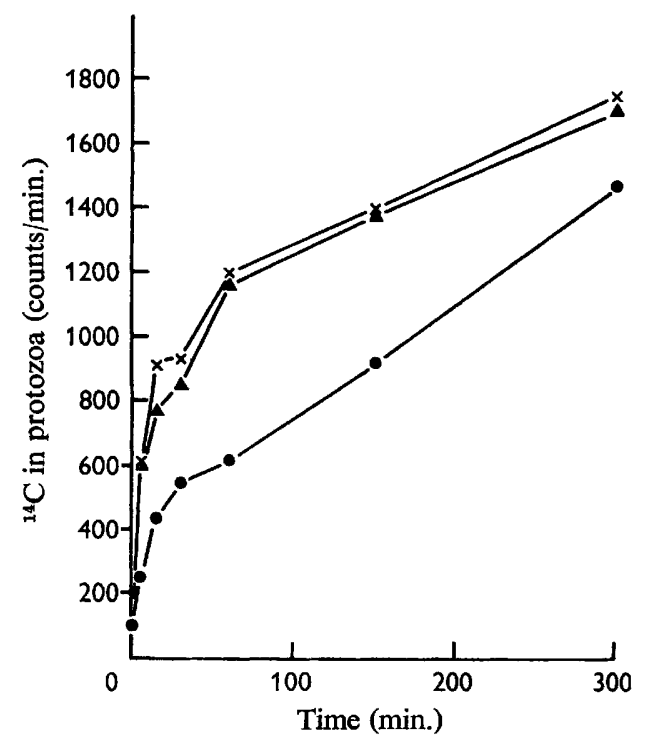

Fig. 1

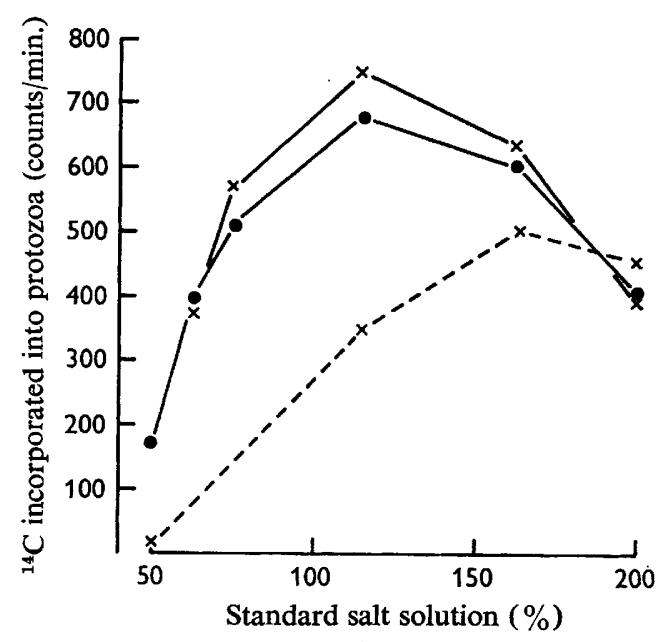

Fig, 2

Fig. 1. Effect of $0.04 \mathrm{M}^{-12} \mathrm{C}-\mathrm{L}-c y s t e i n e(x-\times)$ and $0.02 \mathrm{M}^{-12} \mathrm{C}-\mathrm{L}$-arginine $(\Delta-\Delta)$ on the incorporation of ${ }^{14} \mathrm{C}$ into protozoa Entodinium candatum from uniformly ${ }^{14} \mathrm{C}$-labelled Escherichia coli $(12,300$ counts/min.) (-0).

Fig. 2. Effect of salt concentration on incorporation of ${ }^{14} \mathrm{C}$ from Escherichia coli labelled with individual ${ }^{14} \mathrm{C}$-amino acids into Entodinium caudatum. $-0,{ }^{14} \mathrm{C}$-leucine or ${ }^{14} \mathrm{C}$ glutamic acid labelled $E$. coli incubated without added ${ }^{12} \mathrm{C}$-amino acid. $\times--\times,{ }^{14} \mathrm{C}$ leucine labelled $E$. coli incubated in the presence of $0.01 \mathrm{M}$-L-leucine. $\times-\times,{ }^{14} \mathrm{C}$-glutamic acid labelled $E$. coli incubated in the presence of $0.01 \mathrm{M}-\mathrm{L}$-glutamic acid.

Effect of ${ }^{12} \mathrm{C}$-amino acids and salt concentrations. Figure 2 shows that the maximum incorporation of ${ }^{14} \mathrm{C}$ into Entodinium caudatum from ${ }^{14} \mathrm{C}$-amino acid labelled Escherichia coli occurred at $120 \%$ of the standard salt concentration. The shape of the curve was independent of which amino acid in the bacteria was labelled with ${ }^{14} \mathrm{C}$. However, the effect on the total amount of ${ }^{14} \mathrm{C}$ incorporated by the protozoa of the presence of the ${ }^{12} \mathrm{C}$ form of the amino acid labelled in the bacteria with ${ }^{14} \mathrm{C}$ depended on the amino acid studied. Group 1 amino acids (alanine, arginine, aspartic acid, glutamic acid, serine, Coleman, 1967) had no effect or a slightly stimulatory one on the incorporation of ${ }^{14} \mathrm{C}$, whereas group 2 amino acids (isoleucine, leucine, methionine, phenylalanine, proline, valine) decreased the incorporation at low salt concentrations, but had a slightly stimulatory effect at $200 \%$ of the standard salt concentration.

These experiments were all made with ${ }^{12} \mathrm{C}$-amino acids at a concentration of $0.01 \mathrm{M}$ 
and it has been shown (Coleman, 1967) that at this concentration the uptake of amino acids by the protozoa was not an active process. It was therefore of interest to determine whether low concentrations of a group-2 amino acid, where uptake of the amino acid by the protozoa was an active process, were as effective as higher concentrations in decreasing the incorporation of ${ }^{14} \mathrm{C}$, at low salt concentration, from Escherichia coli labelled with the ${ }^{14} \mathrm{C}$ form of that amino acid. Figure 3 shows that, except at high initial bacteria:protozoa ratios, the same degree of inhibition was obtained at high and low free amino acid concentrations. This suggests that a group 2 amino acid entering the protozoa by either process was equally effective in decreasing the incorporation of ${ }^{14} \mathrm{C}$ from ${ }^{14} \mathrm{C}$-amino acid labelled $E$. coli. At high bacteria:protozoa ratios and low

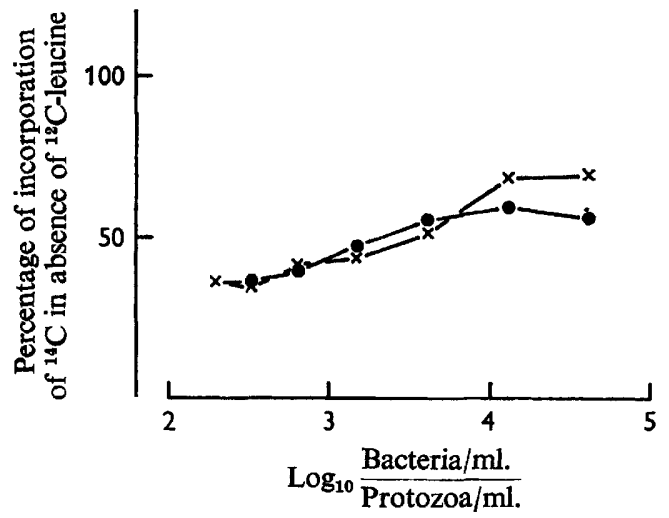

Fig. 3

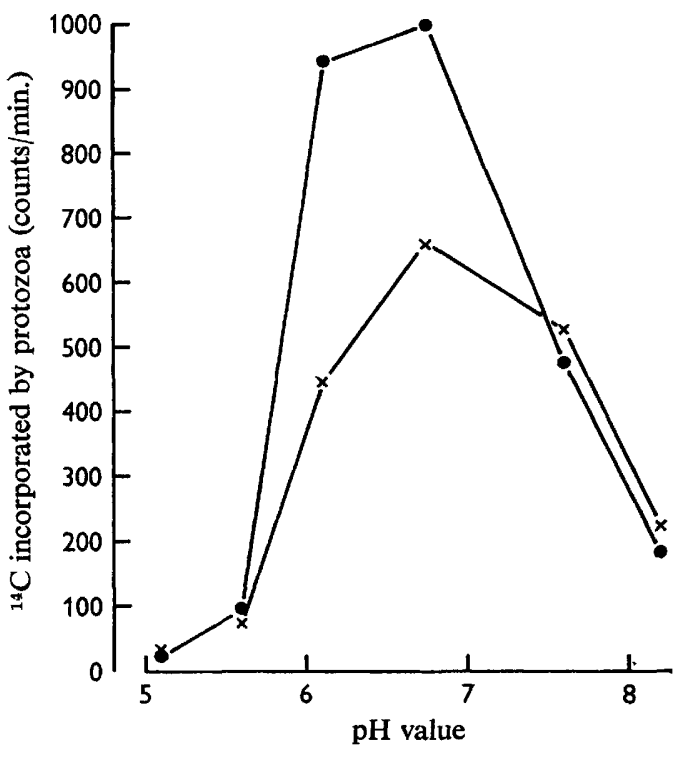

Fig. 4

Fig. 3. Effect of ratio of number of bacteria to number of protozoa present initially on incorporation into Entodinium caudatum of ${ }^{14} \mathrm{C}$ from ${ }^{14} \mathrm{C}$-leucine-labelled Escherichia coli in the presence of $0.001 \mathrm{M}(x-x)$ or $0.01 \mathrm{M}(-0)^{12} \mathrm{C}-\mathrm{L}$-leucine.

Fig. 4. Effect of $\mathrm{pH}$ value on the incorporation of ${ }^{14} \mathrm{C}$ from ${ }^{14} \mathrm{C}$-isoleucine-labelled Escherichia coli by Entodinium caudatum incubated in the absence (-) or presence $(\times-\times)$ of $0.01 \mathrm{M}^{-12} \mathrm{C}-\mathrm{L}-$ isoleucine.

external amino acid concentrations, the quantity of amino acid entering the protozoa from the medium was probably not much greater than that entering by digestion of the bacteria. If it be assumed that amino acids from both sources mix, then under these conditions more bacterial amino acid would be incorporated into protozoal protein than at higher free amino acid concentrations.

Although it has been shown that these results could not have been the result of an effect of the amino acids on the rate of engulfment of Escherichia coli, confirmation was sought by investigating the effect of ${ }^{12} \mathrm{C}$-amino acids on the incorporation into protozoal protein of ${ }^{14} \mathrm{C}$-amino acids from uniformly labelled $E$. coli. In the absence of added free ${ }^{12} \mathrm{C}$-amino acid all the amino acids in the protein of the broken protozoal supernatant fluid were labelled. In the presence of individual ${ }^{12} \mathrm{C}$-amino acids of group 
2 the incorporation of ${ }^{14} \mathrm{C}$ into that amino acid in the protozoal protein was markedly decreased, whereas with ${ }^{12} \mathrm{C}$-amino acids of group 1 , as would have been expected from the above results, the corresponding incorporation was little affected. It was also shown by this method that $0.01 \mathrm{M}^{-12} \mathrm{C}$-glycine, which decreased the rate of engulfment of $E$. coli decreased the incorporation of ${ }^{14} \mathrm{C}$ into glycine to a greater extent than into aspartic acid or glutamic acid.

The effect of $p H$ value. Figure 4 shows the effect of the $\mathrm{pH}$ value of the medium on the incorporation by the protozoa of ${ }^{14} \mathrm{C}$ from ${ }^{14} \mathrm{C}$-isoleucine labelled Escherichia coli. At $\mathrm{pH}$ values above 6.0 the effect on this incorporation of the addition to the medium of $0.01 \mathrm{M}^{-12} \mathrm{C}-\mathrm{L}-$-isoleucine decreased as the $\mathrm{pH}$ value of the medium increased. In contrast, a group-1 amino acid, e.g. glutamic acid, had no effect on the incorporation into the protozoa of ${ }^{14} \mathrm{C}$ from ${ }^{14} \mathrm{C}$-glutamic acid labelled $E$. coli at any $\mathrm{pH}$ value tested.

The effect of temperature. For these experiments the protozoa were incubated for $3 \mathrm{hr}$ in the presence of uniformly ${ }^{14} \mathrm{C}$-labelled Escherichia coli and the incorporation of ${ }^{14} \mathrm{C}$ was measured at various temperatures under otherwise standard conditions. If the number of bacteria engulfed at $39^{\circ}$ be assumed to be 100 then the number taken up was 72 at $43^{\circ}, 18$ at $30^{\circ}$ and 2 at $25^{\circ}$.

The effect of an amino acid analogue. It has been shown previously (Coleman, 1967) that amino acids were probably taken up by the protozoa only by passage through the protozoal cell membranes. The finding that those amino acids which decrease the incorporation of ${ }^{14} \mathrm{C}$ from ${ }^{14} \mathrm{C}$-amino acid labelled Escherichia coli were those which were incorporated most rapidly from the medium (i.e. group-2 amino acids) suggests that the bacteria may be taken up into the protozoal cytoplasm before digestion and evidence has been obtained for this hypothesis (Coleman \& Hall, 1966). If this assumption is correct and if the uptake of a group-2 amino acid can be inhibited by an analogue then, in an experiment on the effect of this amino acid in decreasing the incorporation of ${ }^{14} \mathrm{C}$ from $E$. coli labelled with the ${ }^{14} \mathrm{C}$-form of that amino acid, it may be possible to reverse this inhibition by the addition of the analogue. The only analogue which has been found to abolish completely the active uptake of an amino acid was $p$-fluorophenylalanine which inhibited the incorporation of phenylalanine. Unfortunately all concentrations of $p$-fluorophenylalanine decreased the rate of engulfment of $E$. coli and in the presence of $0.01 \mathrm{M}$ - $p$-fluorophenylalanine the incorporation of ${ }^{14} \mathrm{C}$ from ${ }^{14} \mathrm{C}$-phenylalanine-labelled $E$. coli was only $60 \%$ of that in its absence. However, under these conditions, the further addition of $0.001 \mathrm{M}-{ }^{12} \mathrm{C}-\mathrm{L}-$ phenylalanine decreased the incorporation of ${ }^{14} \mathrm{C}$ by a further $0-10 \%$, whereas in the absence of $p$-fluorophenylalanine, phenylalanine decreased the incorporation by $67 \%$. Despite the inhibition of bacterial engulfment by $p$-fluorophenylalanine this result suggests that $p$-fluorophenylalanine might annul the inhibition of ${ }^{14} \mathrm{C}$-uptake by phenylalanine.

Intracellular products of metabolism. Table 3 shows a typical distribution of ${ }^{14} \mathrm{C}$ in the major cell fractions obtained from protozoa which had metabolized Escherichia coli labelled with any group-2 amino acid in the presence or absence of the ${ }^{12} \mathrm{C}$ form of that amino acid free in the medium. Similar results were obtained by using $E$. coli labelled with a group-1 amino acid, except that the presence of the free amino acid in the medium had no effect on the amount of ${ }^{14} \mathrm{C}$ incorporated. As shown in Table 3, there was a marked increase in the amount of ${ }^{14} \mathrm{C}$ present in the cold TCA-soluble fraction of the broken protozoal supernatant fluid (the protozoal pool) when the 
incubations were done in medium containing high concentrations of salt, and this was observed with $E$. coli labelled with any amino acid. Since the same quantity of ${ }^{14} \mathrm{C}$ labelled bacteria was metabolized at both high and low salt concentrations, it is apparent that at high salt concentrations the ${ }^{14} \mathrm{C}$ was retained by the protozoa, whereas at low concentrations it was released into the medium.

To determine whether any of the bacterial amino acids were converted into other amino acids by the protozoa before incorporation into protozoal protein, the amino acids in the bacterial protein and in the broken protozoal supernatant fluid and pellet fractions were separated by two-dimensional paper chromatography and the position of radioactive spots determined by radio-autography. The protein of Escherichia coli

\section{Table 3. The metabolism of ${ }^{14} \mathrm{C}$-valine labelled Escherichia coli by Entodinium caudatum}

Entodinium caudatum was incubated anaerobically in the presence of Escherichia coli labelled with [U- $\left.{ }^{14} \mathrm{C}\right]$ valine $(53,500$ counts $/ \mathrm{min}$.) in medium containing salts at $60 \%$ (low salt) or $160 \%$ (high salt) of the standard salt concentration in the presence or absence of $0.01 \mathrm{M}^{12} \mathrm{C}-\mathrm{L}$-valine. After incubation for $5 \frac{1}{2} \mathrm{hr}$ the washed protozoa were broken by sonication and the supernatant and pellet fractions separated by centrifugation.

\begin{tabular}{|c|c|c|c|c|c|}
\hline \multirow[b]{3}{*}{${ }^{12} \mathrm{C}$-L-valine present } & \multicolumn{5}{|c|}{ Radioactivity (counts/min.) } \\
\hline & \multicolumn{2}{|c|}{ Low-salt medium } & \multicolumn{2}{|c|}{ High-salt medium } & \multirow{2}{*}{$\begin{array}{c}\text { Initial } \\
E . \text { coli } \\
\text {. }\end{array}$} \\
\hline & - & + & - & + & \\
\hline Medium & 15,000 & 17,100 & 11,800 & 11,700 & . \\
\hline $\begin{array}{l}\text { Broken protozoal super- } \\
\text { natant fluid }\end{array}$ & 5,800 & 3,500 & 9,500 & 8,200 & . \\
\hline Broken protozoal pellet & 5,700 & 2,100 & 7,800 & 5,000 & . \\
\hline \multicolumn{6}{|c|}{ Fractionation of broken protozoal supernatant fluid } \\
\hline $\begin{array}{l}\text { Cold trichloroacetic acid } \\
\text { soluble }\end{array}$ & 1,100 & 1,300 & 4,500 & 4,700 & 700 \\
\hline Ethanol-soluble protein & 980 & 520 & 1,100 & 580 & 6,700 \\
\hline Lipid & 330 & 160 & 230 & 240 & 850 \\
\hline Nucleic acid & 220 & 40 & 175 & 80 & 1,800 \\
\hline Residual protein & 2,700 & 1,400 & 2,800 & 2,600 & 40,000 \\
\hline
\end{tabular}

which was prepared labelled with ${ }^{14} \mathrm{C}$-alanine, arginine, glutamic acid, glycine, isoleucine, leucine, lysine, methionine, phenylalanine, proline, serine or valine contained $90-100 \%$ of the ${ }^{14} \mathrm{C}$ in the form of the one amino acid. The protein of both the protozoal fractions always contained only the same ${ }^{14} \mathrm{C}$-amino acids as were present in the original $E$. coli, and the proportion of the total ${ }^{14} \mathrm{C}$ present in the principal amino acid was never less than that in the same amino acid in the bacteria. It was not possible to prepare ${ }^{14} \mathrm{C}$-aspartic acid labelled $E$. coli which contained over $90 \%$ of the total ${ }^{14} \mathrm{C}$ as aspartic acid, and although bacterial aspartic acid was apparently incorporated into the protozoal protein it was not possible to obtain unambiguous results. No evidence was obtained in any experiment for any amino acid interconversion by the protozoa.

The constituents of the protozoal pool. Most of the experiments on the constituents of the pool during the metabolism of ${ }^{14} \mathrm{C}$-amino acid labelled Escherichia coli were made after incubation in the high salt concentration medium ( $200 \%$ of standard) in order to take advantage of the larger quantity of ${ }^{14} \mathrm{C}$ present in this fraction under these 
conditions. Figures 5 and 6 show the time-course for the appearance of ${ }^{14} \mathrm{C}$ in the cold TCA-soluble fraction during the metabolism of $E$. coli labelled with ${ }^{14} \mathrm{C}$-glutamic acid (group 1) or ${ }^{14} \mathrm{C}$-leucine (group 2). With the former, the ${ }^{14} \mathrm{C}$ in the pool continued to increase throughout the experiment, but with the latter it reached a constant value after $2 \mathrm{hr}$. The constituents of the pool during the metabolism of $E$. coli labelled with various amino acids were as follows.

Alanine. $65 \%$ alanine, $28 \% \mathrm{~N}$-acetylalanine, $7 \% \mathrm{~N}$-formylalanine. The relative proportions of these three compounds were very variable, and although the above result was typical, in one experiment there was $90 \%$ alanine and in another equal quantities of each compound. The properties were not altered by changes in the salt concentration or by replacement of the sodium propionate in the medium with sodium

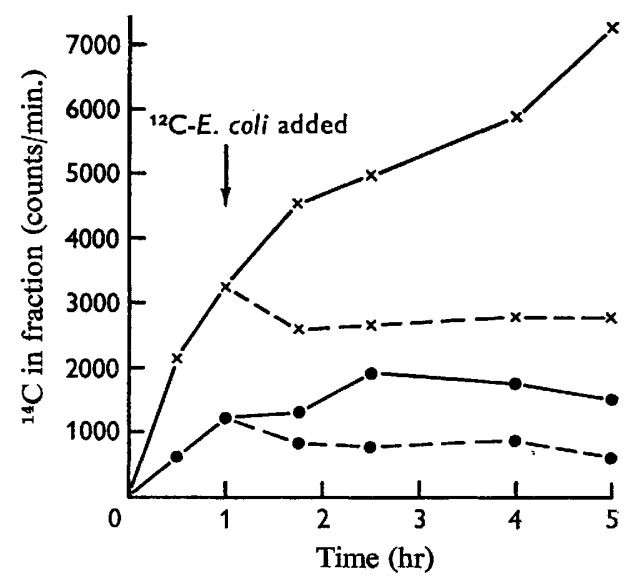

Fig. 5

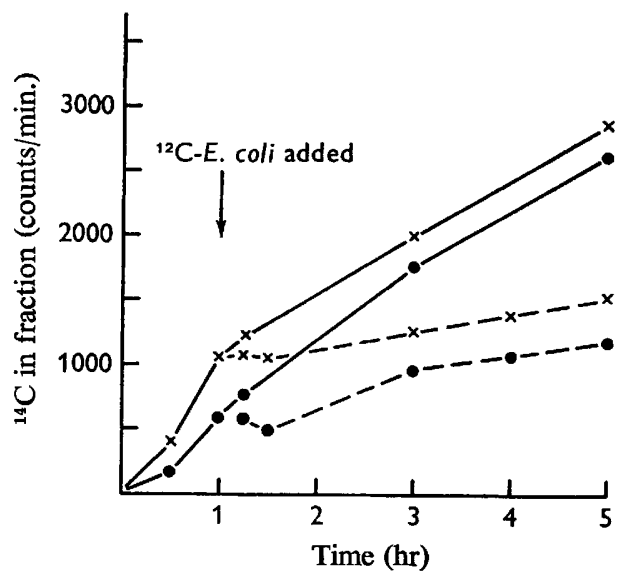

Fig. 6

Fig. 5. Effect of addition of tenfold excess of ${ }^{12} \mathrm{C}$-Escherichia coli after $1 \mathrm{hr}$ on the metabolism of ${ }^{14} \mathrm{C}$-leucine labelled $E$. coli by washed suspensions of Entodinium caudatum. ${ }^{14} \mathrm{C}$ in cold TCA-soluble fraction of broken protozoal supernatant fluid; $\times,{ }^{14} \mathrm{C}$ in protein of broken protozoal supernatant fluid; ---, ${ }^{14} \mathrm{C}$ in fractions after addition of ${ }^{12} \mathrm{C}$-Escherichia coli.

Fig. 6. Effect of addition of tenfold excess of ${ }^{12} \mathrm{C}$-Escherichia coli after $1 \mathrm{hr}$ on the metabolism of ${ }^{14} \mathrm{C}$-glutamic acid labelled $E$. coli by washed suspensions of Entodinium caudatum. , ${ }^{14} \mathrm{C}$ in cold TCA-soluble fraction of the broken protozoal supernatant fluid; $\times,{ }^{14} \mathrm{C}$ in protein of broken protozoal supernatant fluid; ---, ${ }^{14} \mathrm{C}$ in fractions after addition of ${ }^{12}$ C-Escherichia coli.

bicarbonate. Attempts to formally identify the acetyl or formyl parts of amino acid derivatives were unsuccessful because $(a)$ insufficient material was present for chemical identification and $(b)$ the derivatives were not labelled by incubation of protozoa with ${ }^{12} \mathrm{C}$-Escherichia coli and ${ }^{14} \mathrm{C}$-acetate or ${ }^{14} \mathrm{C}$-formate.

Glutamic acid. $35 \%$ glutamic acid, $65 \% \mathrm{~N}$-formylglutamine.

Glycine. $100 \% \mathrm{~N}$-acetylglycine.

Isoleucine, leucine, methionine, phenylalanine and valine. One compound only which was the amino acid labelled in the bacteria. No trace of any $N$-formyl or $N$-acetyl derivative was found.

Arginine and lysine. The pool obtained from protozoa which had metabolized Escherichia coli labelled with these basic amino acids contained at least four ${ }^{14} \mathrm{C}$ - 
labelled compounds, one of which was the free amino acid. The other compounds were not identified, but were presumed to be acetyl or formyl derivatives of the amino acids.

Serine. No clearly defined spots were produced on chromatography.

To determine the metabolic function of these compounds in the protozoal pool, suspensions of Entodinium caudatum were allowed to metabolize Escherichia coli labelled with ${ }^{14} \mathrm{C}$-leucine or ${ }^{14} \mathrm{C}$-glutamic acid for $1 \mathrm{hr}$ and then a tenfold excess of ${ }^{12} \mathrm{C}-E$. coli was added to the medium and changes in the amount of ${ }^{14} \mathrm{C}$ in the pool measured (Figs. 5, 6). With both amino acids the addition of the ${ }^{12} \mathrm{C}-E$. coli immediately stopped the incorporation of ${ }^{14} \mathrm{C}$ into the protozoal pool and the protein of the broken protozoal supernatant fluid. However, there was no sharp decrease in the amount of ${ }^{14} \mathrm{C}$ in the pool as might have been expected if the pool amino acids and

Table 4. Products of the metabolism of the amino acids in Escherichia coli by Entodinium caudatum

Protozoa were incubated anaerobically in the presence of Escherichia coli labelled with the ${ }^{14} \mathrm{C}$-amino acids shown for $4-5 \mathrm{hr}$. The quantities of the various products in the medium were determined as described in the text and the results are expressed in moles/100 moles of carbon incorporated into the protozoa.

\begin{tabular}{|c|c|c|c|}
\hline & \multicolumn{3}{|c|}{${ }^{14} \mathrm{C}$-recovered in: } \\
\hline & $\begin{array}{l}\text { Volatile } \\
\text { acid }\end{array}$ & $\mathrm{CO}_{2}$ & $\begin{array}{c}\text { Non-volatile } \\
\text { material }\end{array}$ \\
\hline [U- ${ }^{14} \mathrm{C}$ ]alanine & 79 & 18 & 28 \\
\hline$\left[1-{ }^{14} \mathrm{C}\right]$ alanine & 24 & 62 & 28 \\
\hline [U-14 C]glutamic acid & 6 & 5 & 26 \\
\hline [U-14 $\mathrm{C}$ ]glycine & 8 & 1 & 26 \\
\hline [U-14 C]isoleucine & 38 & 6 & 28 \\
\hline [U-14 C]leucine & 39 & 7 & 57 \\
\hline$\left[1-{ }^{14} \mathrm{C}\right]$ leucine & 32 & 133 & 31 \\
\hline [U-14 C]lysine & 3 & 1 & 23 \\
\hline [U-14 C]phenylalanine & 15 & 3 & 45 \\
\hline [U-14 C]proline & 21 & 3 & 86 \\
\hline [U-14 C]valine & 74 & 9 & 40 \\
\hline
\end{tabular}

amino acid derivatives were on the pathway from bacterial protein to protozoal protein. It was not possible to use saturating concentrations of ${ }^{14} \mathrm{C}$-labelled bacteria for these experiments and still be able to add a ten-times excess of ${ }^{12} \mathrm{C}-E$. coli as the medium would be almost solid with bacteria, and under non-saturating conditions aberrant results may be obtained. It is possible that even if saturating conditions were used, that the bacteria might be killed and digested inside the protozoa in the order in which they were engulfed and then dilution of the digestion products of the ${ }^{14} \mathrm{C}$ labelled bacteria with those of the ${ }^{12} \mathrm{C}$-bacteria would not occur for some time. As there was a lag of $60 \mathrm{~min}$. before significant quantities of non-volatile ${ }^{14} \mathrm{C}$ were liberated into the medium after the addition of ${ }^{14} \mathrm{C}$-leucine labelled $E$. coli to protozoal suspensions, and as there was little decrease in the amount of ${ }^{14} \mathrm{C}$ incorporated in the presence of $0.01 \mathrm{M}^{-12} \mathrm{C}-\mathrm{L}-$ leucine under these conditions for $60 \mathrm{~min}$., it is suggested that the addition of ${ }^{12} \mathrm{C}-E$. coli should effect the amount of ${ }^{14} \mathrm{C}$ in the pool within $90 \mathrm{~min}$. of its addition if these pool constituents were intermediates. As the amount of ${ }^{14} \mathrm{C}$ in the pool in the experiment with ${ }^{14} \mathrm{C}$-leucine labelled $E$. coli decreased by only $27 \%$ in 90 min. and $50 \%$ in $240 \mathrm{~min}$., this is taken as evidence that the pool constituents were not intermediates between bacterial and protozoal protein. 
Extracellular products of metabolism. On incubation of washed suspensions of Escherichia coli labelled with specific ${ }^{14} \mathrm{C}$-amino acids with Entodinium caudatum, approximately half of the ${ }^{14} \mathrm{C}$ was incorporated by the protozoa and the remainder appeared as $\mathrm{CO}_{2}$, volatile acids or as non-volatile materials in the medium (Table 4). The time-course for the metabolism of ${ }^{14} \mathrm{C}$-amino acid labelled $E$. coli was similar to that shown previously for uniformly ${ }^{14} \mathrm{C}$-labelled $E$. coli (Coleman, 1964). The molecular weight of the ${ }^{14} \mathrm{C}$-labelled compounds in the medium was investigated by passage of the material through a column of Sephadex G50 (exclusion molecular weight $10,000)$. After $1-5 \mathrm{hr}$ of incubation, only $11 \%$ of the non-volatile ${ }^{14} \mathrm{C}$ in the supernatant fluid was recovered in the high molecular weight peak, showing that the bacteria were completely digested and not broken up into large fragments. The metabolites of $E$. coli labelled with individual ${ }^{14} \mathrm{C}$-amino acids have been identified as follows.

Alanine. The volatile fatty acids produced from $\left[\mathrm{U}-{ }^{14} \mathrm{C}\right] \mathrm{alanine}-\mathrm{labelled}$ Escherichia coli have been identified by chromatography in solvent $\mathrm{K}$ (Coleman, 1967) as formic acid $(20 \%)$ and acetic acid $(80 \%)$ with an acetic acid:formic acid $+\mathrm{CO}_{2}$ ratio of 1.9:1. Since two to three times as much $\mathrm{CO}_{2}$ as volatile acid was produced in the presence of $\left[1-{ }^{14} \mathrm{C}\right]$ alanine-labelled $E$. coli and since the acid was principally formic acid, this suggests that the carboxyl carbon of alanine was liberated as $\mathrm{CO}_{2}$ or formate, and that the acetate was derived from $\mathrm{C} 2$ and $\mathrm{C} 3$. The non-volatile ${ }^{14} \mathrm{C}$-material in the medium was $80-90 \%$ alanine and the remainder was probably $\mathrm{N}$-acetylalanine.

Glutamic acid. The non-volatile material in the medium was 50-70\% glutamic acid and $30-50 \% N$-formylglutamic acid or $\alpha$ - $N$-formylglutamine.

Glycine. The non-volatile material in the medium was $60-70 \%$ glycine and $30-40 \%$ $\mathrm{N}$-acetylglycine. When ${ }^{12} \mathrm{C}$-glycine was present during the incubation the $150 \%$ increase in the amount of non-volatile ${ }^{14} \mathrm{C}$ present was due solely to an increase in the amount of glycine.

Isoleucine. The ${ }^{14} \mathrm{C}$-volatile acid was identified as a $\mathrm{C}_{5}$ acid by chromatography in Solvent K (Coleman, 1967). As it was not possible to resolve the four structural isomers of the valeric acid by paper chromatography the acid was chromatographed on a column of buffered celite (Bueding \& Yale, 1951) and identified as either isovaleric or $\alpha$-methylbutyric acid. To distinguish between these, equal quantities were added to a large excess of the ${ }^{12} \mathrm{C}$ form of each of these acids in turn and then the $p$-bromophenacyl esters prepared, recrystallized twice (Judefind \& Reid, 1919) and the ${ }^{14} \mathrm{C}$ in the crystals determined. It was hoped that when the ${ }^{12} \mathrm{C}$ and ${ }^{14} \mathrm{C}$ acids were different no ${ }^{14} \mathrm{C}$ would appear in the crystals, but that when they were the same appreciable quantities of ${ }^{14} \mathrm{C}$ would be present. In the presence of ${ }^{12} \mathrm{C}$-isovaleric acid and ${ }^{12} \mathrm{C}-\alpha$-methylbutyric acid, respectively, the recovery of ${ }^{14} \mathrm{C}$ was $7 \%$ and $31 \%$, respectively, showing that the $\mathrm{C}_{5}$ acid was probably $\alpha$-methylbutyric acid.

As the formation of $\alpha$-methylbutyrate from isoleucine must involve the loss of one carbon atom, an attempt was made to measure the amount of ${ }^{14} \mathrm{CO}_{2}$ produced during the metabolism of [U-14 C]isoleucine labelled Escherichia coli. Table 4 shows that the volatile acid: $\mathrm{CO}_{2}$ ratio was $6 \cdot 3: 1$ as compared with the theoretical value of $5 \cdot 0: 1$ for a decarboxylation of isoleucine; this result is consistent with formation of $\alpha$-methylbutyrate by this mechanism. The non-volatile material in the medium was ${ }^{14} \mathrm{C}$-isoleucine.

Leucine. The volatile fatty acid produced from ${ }^{14} \mathrm{C}$-leucine-labelled Escherichia coli was identified in the same way as that from ${ }^{14} \mathrm{C}$-isoleucine-labelled $E$. coli except that 
the ${ }^{14} \mathrm{C}$ recovered in the $p$-bromophenacyl esters was $35 \%$ with ${ }^{12} \mathrm{C}$-isovaleric acid and $4 \%$ with ${ }^{12} \mathrm{C}-\alpha$-methylbutyric acid, showing that the volatile acid was isovaleric acid. The production of ${ }^{14} \mathrm{CO}_{2}$ from [U-14 $\left.\mathrm{C}\right]$ leucine-labelled $E$. coli was also measured and the volatile acid: $\mathrm{CO}_{2}$ ratio found to be 5.6:1 (Table 4) which agrees well with the theoretical value of $5 \cdot 0: 1$ for the formation of isovaleric acid from leucine by decarboxylation. In an attempt to prove that it was carbon-atom 1 of leucine that was liberated as $\mathrm{CO}_{2}$ a similar experiment was done with $\left[1{ }^{14} \mathrm{C}\right]$ leucine-labelled $E$. coli (Table 4) and under these conditions four times as much ${ }^{14} \mathrm{CO}_{2}$ as ${ }^{14} \mathrm{C}$-volatile acid was produced, indicating that most of the $\mathrm{CO}_{2}$ came from carbon-atom 1 of leucine. The nonvolatile material in the medium was ${ }^{14} \mathrm{C}$-leucine; no trace of $\mathrm{N}$-acetylleucine was found.

Phenylalanine. Two non-volatile materials were present in the medium, one of which was extractable by ether from the acidified solution and shown to be phenylacetic acid. The non-extractable compound was free phenylalanine. The amount of phenylacetic acid produced from $\left[\mathrm{U}-^{14} \mathrm{C}\right]$ phenylalanine-labelled Escherichia coli was deduced from the total non-volatile ${ }^{14} \mathrm{C}$ in the medium, and the fraction present as phenylacetic acid after separation of the two compounds by chromatography in solvent $\mathrm{A}$ or J. Under these conditions the phenylacetic acid: $\mathrm{CO}_{2}$ ratio was $3 \cdot 6: 1$ as compared with a theoretical value of $8: 1$ for the production of phenylacetic acid from phenylalanine by decarboxylation. This suggests that the phenylacetic acid may have undergone further metabolism.

Valine. The volatile fatty acid produced during the metabolism of ${ }^{14} \mathrm{C}$-valinelabelled Escherichia coli was identified as isobutyric acid by the same methods as those used to identify $\alpha$-methylbutyric acid as a product of ${ }^{14} \mathrm{C}$-isoleucine metabolism. Table 4 shows that the volatile acid $/ \mathrm{CO}_{2}$ ratio was $8 \cdot 2: 1$ which compared poorly with a theoretical value of $4 \cdot 0: 1$.

\section{Metabolism of ${ }^{14}$ C-amino acid labelled Escherichia coli by multiplying Entodinium caudatum}

It is possible that non-multiplying suspensions of protozoa may be unable to carry out biosynthetic reactions that normally occur in growing protozoa where new cellular material is being formed. To investigate this, Entodinium caudatum was allowed to grow in the presence of Escherichia coli labelled with ${ }^{14} \mathrm{C}$-amino acids under the conditions described previously (Coleman, 1964) until the number of protozoa had at least doubled. In a typical experiment with $E$. coli labelled with ${ }^{14} \mathrm{C}$-glutamic acid, the number of protozoa increased from $16,500 / \mathrm{ml}$. to $34,200 / \mathrm{ml}$. in $48 \mathrm{hr} ; 97 \%$ of the bacteria were metabolized and $28 \%$ of the ${ }^{14} \mathrm{C}$ was retained by the protozoa, the remainder appearing in the supernatant fluid. Of the ${ }^{14} \mathrm{C}$ in the protozoa $43 \%$ was in the broken protozoal supernatant fluid (pool) after breakage of the protozoa and $90 \%$ of the ${ }^{14} \mathrm{C}$ in this fraction was protein glutamic acid. When the protozoa were allowed to grow under the same conditions in the presence of $0.01 \mathrm{M}^{-12} \mathrm{C}-\mathrm{L}$-glutamic acid the incorporation of ${ }^{14} \mathrm{C}$ into the protozoa was decreased by $19 \%$ as compared with $97 \%$ when the amino acid studied throughout was leucine (Coleman, 1964).

The metabolism of Escherichia coli labelled with ${ }^{14} \mathrm{C}$-alanine, arginine, glutamic acid, glycine, isoleucine, leucine, lysine, phenylalanine, serine or valine was studied under conditions which allowed protozoal growth, and for all these amino acids no evidence was obtained for any amino acid interconversions. In the presence of the 
${ }^{12} \mathrm{C}$-form of the ${ }^{14} \mathrm{C}$-amino acid present in the bacteria ${ }^{14} \mathrm{C}$ incorporation into the protozoa was decreased by $20-50 \%$ for group- 1 amino acids and by over $90 \%$ for group-2 amino acids. The greater effect with both groups under growth conditions as compared with non-multiplying protozoa was probably associated with the longer incubation times. This meant that the time taken for the bacteria to be engulfed, killed and digested was a much smaller proportion of the total time allowed and there was more time for equilibration with the free amino acid entering from the medium.

\section{DISCUSSION}

In their natural habitat of the sheep rumen, entodiniomorphid protozoa live in a medium which is poor in readily metabolizable compounds such as sugars and amino acids but contains up to $10^{10}$ bacteria/ml. (Bryant \& Robinson, 1961). In view of this it is not unexpected that Entodinium caudatum should utilize amino acids much more economically from intact bacteria than from free amino acids in the medium. There has been speculation (Coleman, 1963) that $E$. caudatum might have been able to synthesize amino acids from carbohydrate which it engulfed as starch grains and ammonia which were present in rumen liquor. However, the present results indicate that $E$. caudatum probably satisfies its amino acid requirements from the digestion products of bacteria. Although the incorporations measured in experiments with nonmultiplying protozoa may be the result of protein turnover those obtained with growing organisms were probably due to the synthesis of new protein. Other results with ${ }^{14} \mathrm{C}$-labelled-starch grains have shown that little protein was synthesized from carbohydrate even by growing protozoa. The inability of E. caudatum to biosynthesize or interconvert amino acids is probably the result of a gradual loss of enzymes from the time when this protozoon, now found nowhere else, first invaded the rumen. This loss would have been brought about by growth on micro-organisms which probably contain all the low-molecular-weight nitrogenous compounds required by a living cell. The protozoa have, however, retained the ability to oxidatively deaminate some amino acids according to the reaction.

$$
\text { R. } \mathrm{CH}\left(\mathrm{NH}_{2}\right) \mathrm{COOH}+2 \mathrm{H}_{2} \mathrm{O} \rightarrow \mathrm{R} \cdot \mathrm{COOH}+\mathrm{CO}_{2}+\left(\mathrm{NH}_{3}\right)+(4 \mathrm{H}) .
$$

These results are in contrast to those of Abou Akkada \& Howard (1962) who considered that non-multiplying suspensions of Entodinium caudatum prepared from the rumen did not deaminate amino acids or utilize casein for the synthesis of cellular constituents. However, these authors measured changes in the amounts of nitrogenous materials and this method is not sensitive to small changes in the amount of any compound present. In contrast to the slow catabolism of amino acids, starch grains are rapidly broken down to $\mathrm{CO}_{2}, \mathrm{H}_{2}$, formic, acetic, propionic and butyric acids (Abou Akkada \& Howard, 1960), and since the protozoa in the present experiments contained starch grains a ready supply of 'active' acetate and formate was probably available for acetylation or formylation of amino acids. The exact reactions which occurred must have depended on the enzymes present and only the group-1 amino acids and glycine were ever found to be $N$-substituted. However, as no evidence was obtained that these pool constituents were intermediates in the synthesis of protozoal protein they were probably by-products of protozoal metabolism. Since the same compounds were found in the pool and the medium it seems probable that they gradually diffused out into the medium, especially if the salt concentration was low. 
I wish to thank Mr G. A. Embleton for inserting permanent rumen cannulae into the sheep used to provide rumen fluid for the routine maintenance of the protozoa, the members of the Sub-Department of Chemical Microbiology, Biochemistry Department, University of Cambridge, for their helpful advice and criticism, and Miss B. Hanzl for valuable technical assistance.

\section{REFERENCES}

Abou Akkada, A. R. \& Howard, B. H. (1960). The biochemistry of rumen protozoa. 3. The carbohydrate metabolism of entodinium. Biochem. J. 76, 445.

Abou Akkada, A. R. \& HowaRd, B. H. (1962). The biochemistry of rumen protozoa. 5. The nitrogen metabolism of entodinium. Biochem J. 82, 313.

BRYANT, M. P. \& Robinson, I. M. (1961). An improved nonselective culture medium for ruminal bacteria and its use in determining diurnal variation in numbers of bacteria in the rumen. J. Dairy Sci. 44, 1446.

Bubding, E. \& Yale, H. W. (1951). Production of $\alpha$ methyl butyric acid by bacteria free Ascaris lumbricoides. J. biol. Chem. 193, 411.

Coleman, G. S. (1956). The dissimilation of amino acids by Rhodospirillum rubrum. J. gen. Microbiol. $15,248$.

Colmman, G. S. (1958). Maintenance of oligotrich protozoa from the sheep rumen in vitro. Nature, Lond. 182, 1104.

Coleman, G. S. (1960). Effect of penicillin on the maintenance of rumen oligotrich protozoa. Nature, Lond. 187, 518.

Coleman, G. S. (1962). The preparation and survival of almost bacteria free suspensions of Entodinium caudatum. J. gen. Microbiol. $28,271$.

Coleman, G. S. (1963). The growth and metabolism of rumen ciliate protozoa. Symp. Soc. gen. Microbiol. 13, 298.

Coleman, G. S. (1964). The metabolism of Escherichia coli and other bacteria by Entodinium caudatum. J. gen. Microbiol. 37, 209.

Colmman, G. S. (1967). The metabolism of free amino acids by washed suspensions of the rumen ciliate Entodinium caudatum. J. gen. Microbiol. 47, 433.

Colbman, G. S. \& Hall, F. J. (1966). Bacterial feeding by the rumen ciliate Entodinium caudatum. J. gen. Microbiol. 44, iii.

Judefind, W. L. \& REID, E. E. (1919). The identification of acids. V. Phenacyl esters. J. Am. chem. Soc. 41, 75.

Potter, V. R. \& ElvehJem, C. A. (1936). A modified method of the study of tissue oxidations. J. biol. Chem. 114, 495.

Roberts, R. B., Abelson, P. H., Cowie, D. E., Bolton, E. T. \& Britten, R. J. (1955). Studies on Biosynthesis in Escherichia coli. Publs Carnegie Instn no. 607.

WhITE, R. W. (1966). Bacterial population of a rumen ciliate Entodinium caudatum cultured in vitro. J. gen. Microbiol. 42, xii. 